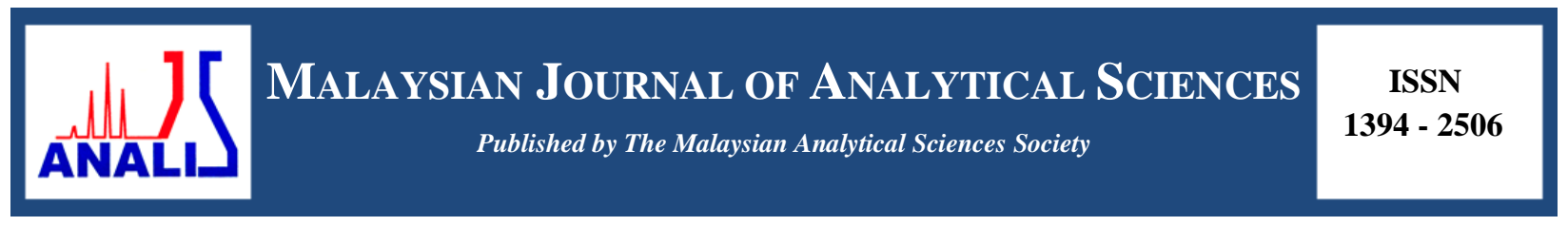

\title{
PHOTOCATALYTIC DEGRADATION OF PHENOL DERIVATIVES OVER SILVER SUPPORTED ON MESOPOROUS TITANIA NANOPARTICLES
}

\section{(Degradasi Fotomangkinan Terbitan Fenol Ke Atas Perak Disokong Pada Titania Nanopartikel Berliang Meso)}

\author{
Nur Farhana Jaafar ${ }^{1}$ and Aishah Abdul Jalil ${ }^{2,3}$ \\ ${ }^{1}$ School of Chemical Sciences, \\ Universiti Sains Malaysia, 11800 USM Penang, Malaysia \\ ${ }^{2}$ Centre for Hydrogen Energy, Institute of Future Energy \\ ${ }^{3}$ Department of Chemical Engineering, Faculty of Chemical and Energy Engineering \\ Universiti Teknologi Malaysia, 81310 UTM Johor Bahru, Johor, Malaysia \\ *Corresponding author: nurfarhana@usm.my
}

Received: 15 May 2018; Accepted: 23 July 2018

\begin{abstract}
In this study, the potential of silver supported on mesoporous titania nanoparticles (Ag-MTN) as visible-light-driven photocatalyst was investigated for the degradation of phenol derivatives. Characterisation results illustrated that the presence of Ag reduced the band gap of MTN and increased the number of oxygen vacancies (OV) and $\mathrm{Ti}^{3+}$ site defect (TSD). The presence of both properties is among the important factors that need to be considered for catalyst properties in order to achieve effective photocatalytic degradation under visible light. The photoactivity of the catalyst was also significantly influenced by the presence of $\mathrm{Ag}$, which acted as an electron trap that enhanced electron-hole separation. The ability of Ag-MTN to degrade phenol derivatives [phenol $(\mathrm{Ph}), 2$-chlorophenol (2-CP), 2,4-dichlorophenol (2,4-diCP), and 4-acetamidophenol (4-AcePh)] was compared with commercial $\mathrm{TiO}_{2}$ and $\mathrm{MTN}$. The percentage degradation of phenol derivatives was in the following order: $\mathrm{TiO}_{2}<$ MTN < Ag-MTN. This indicated that the presence of Ag in MTN effectively enhanced the photoactivity of MTN towards the degradation of phenol derivatives.
\end{abstract}

Keywords: Ag-MTN catalyst, electron trapper, visible light, phenol derivatives

\section{Abstrak}

Dalam kajian ini, potensi perak disokong pada nanopartikel titania berliang meso (Ag-MTN) sebagai fotomangkin-pemacucahaya nampak telah disiasat bagi degradasi terbitan fenol. Keputusan pencirian menunjukkan kehadiran Ag mengurangkan luang jalur MTN dan meningkatkan bilangan kekosongan oksigen (OV) dan permukaan $\mathrm{Ti}^{3+}$ cacat (TSD). Kehadiran kedua-dua sifat adalah antara faktor penting yang perlu dipertimbangkan bagi sifat mangkin bagi mencapai degradasi fotomangkin yang efektif di bawah cahaya nampak. Fotoaktiviti bagi mangkin juga sangat dipengaruhi dengan kehadiran Ag di mana bertindak sebagai perangkap elektron yang meningkatkan pemisahan elektron-lubang. Keupayaan Ag-MTN untuk degradasi terbitan fenol [fenol (Ph), 2-klorofenol (2-CP), 2,4-diklorofenol (2,4-diCP) dan 4-asetamidofenol (4-AcePh)] telah dibandingkan dengan TiO ${ }_{2}$ komersial dan MTN. Peratusan degradasi bagi terbitan fenol telah mengikuti susunan: $\mathrm{TiO}_{2}<\mathrm{MTN}<\mathrm{Ag}-\mathrm{MTN}$. Ini menunjukkan kehadiran Ag dalam MTN berkesan meningkatan fotoaktiviti bagi MTN terhadap degradasi terbitan fenol.

Kata kunci: mangkin Ag-MTN, perangkap elektron, cahaya nampak, terbitan fenol 


\section{Introduction}

Phenol derivatives are widely used as intermediates in pulp, paper, biocides, cleaning agents, dyes, preservatives, and pesticides industries [1]. However, the release of phenol derivatives into aqueous environmental systems has raised concerns due to their high toxicity, high stability, and potentially carcinogenic [2]. The carbon-halogen bond causes recalcitrance of phenol derivatives, which is cleaved with great difficulty and the stability of their aromatic structure, resulting in their growth in nature. As a result, the Department of Environment (DOE) Malaysia has gazetted the allowable limits as in Environmental Quality (Sewage and Industrial Effluent) Regulations, 1979, that this pollutant should be treated to be less than $1 \mathrm{mg} \mathrm{L}^{-1}$ before being discharged to water bodies.

There are ongoing studies on the appropriate methods for eliminating these toxic organic compounds from aqueous systems due to the adverse effect caused by phenol derivatives on the environment and humans. Several removal techniques including ion exchange, adsorption, and solvent extraction have been proposed for removing or treating phenol derivatives [3]. However, these techniques incur high cost, is time consuming, and can be responsible for generation of secondary pollutants [4]. Heterogeneous photocatalysts such as $\mathrm{TiO}_{2}, \mathrm{FeOOH}, \mathrm{ZnO}, \mathrm{CuO}$, and $\mathrm{ZrO}_{2}$ are commonly used in advanced oxidation process (AOP) for removal of this recalcitrant pollutant. Among them, $\mathrm{TiO}_{2}$ shows superior performance due to its strong oxidising power and chemical inertness [5]. However, photocatalytic application of $\mathrm{TiO}_{2}$ has been limited by its high photogenerated electron-hole recombination rate caused by the rapid transfer of electrons generated from the semiconductors to the metal particles and can only be excited by UV-light irradiation [6]. Hence, many approaches have been reported to overcome this problem such as varying the synthesis method in order to obtain a mesoporous structure for enhancing its efficiency and modification with other semiconductors or noble metals.

Nowadays, self-modified mesoporous titania nanoparticles (MTN) containing oxygen vacancies (OV) and $\mathrm{Ti}^{3+}$ site defects (TSD) are one of the approaches in light-absorption modification for $\mathrm{TiO}_{2}$ to increase its photocatalytic performance [7]. Microwave (MW)-assisted method is one of the efficient methods that have been studied to synthesise MTN since it could provide a uniform and fast reaction environment to produce mesoporous materials [8]. Besides, $\mathrm{Ag}^{0}$ is one of the potential photocatalysts to be used in the doping with $\mathrm{TiO}_{2}$ due to its properties that delay the recombination of photogenerated electron-hole pairs by acting as an electron trap [9]. Various methods have been used to activate $\mathrm{Ag}^{+}$to $\mathrm{Ag}^{0}$ for synthesising Ag-MTN including electrochemical method, which is a simple activation of $\mathrm{Ag}^{0}$ onto MTN without the need of high temperature or longer time. Therefore, we reported the synergistic effect between $\mathrm{Ag}^{0}$ and MTN towards the degradation of phenol derivatives under visible light.

\section{Reagents, material and apparatus}

\section{Materials and Methods}

$\mathrm{TiO}_{2}$ powder catalyst, JRC-TiO $2-2$, was supplied by the Catalysis Society of Japan and titanium (IV) isopropoxide (TTIP) was bought from Sigma Aldrich. Ag and Pt plates of greater than 99\% purity were used as electrodes and were obtained from Nilaco, Japan. N,N-dimethylformamide (DMF), cetyltrimethylammonium bromide (CTAB), propanol, phenol $(\mathrm{Ph}), 2$-chlorophenol (2-CP), 2,4-dichlorophenol (2,4-diCP), 4-acetamidophenol (4-AcePh), and perchloric acid were purchased from MERCK, Malaysia. Naphthalene and tetraethylammonium bromide solution were obtained from Fluka Chemical and acetone was purchased from HmbG Chemical. Sodium hydroxide (NaOH), ammonium hydroxide $\left(\mathrm{NH}_{4} \mathrm{OH}\right)$, and hydrochloric acid $(\mathrm{HCl})$ were purchased from QREC $^{\mathrm{TM}}$ and methanol was purchased from RPE Reagent Pure Erba. Tetraethylammonium perchlorate (TEAP), which was used as a supporting electrolyte in the electrolysis, was prepared in accordance with the procedure reported in the literature [10].

\section{Preparation of catalyst: Synthesis of mesoporous titania nanoparticles}

Mesoporous titania nanoparticles (MTN) was synthesised by dissolving $4.68 \mathrm{~g}$ of CTAB in $720 \mathrm{ml}$ of distilled water, $120 \mathrm{ml}$ of propanol, and $29 \mathrm{ml}$ of $28 \%$ ammonia solution. The mixture was stirred continuously for 30 minutes at $323 \mathrm{~K}$ in water bath. Then, the temperature of water bath was increased to $353 \mathrm{~K}$, followed by the addition of $5.7 \mathrm{~mL}$ TTIP, and the mixture was stirred for another 2 hours. The white solution was transferred into a beaker after 2 hours of stirring and placed in a microwave. The heating continued under $0.56 \mathrm{Wg}^{-1}$ as the power density of microwave until a sol-gel of $\mathrm{TiO}_{2}$ was formed. The obtained product was collected and dried overnight in an oven before calcination at $873 \mathrm{~K}$ for 3 hours. 


\section{Synthesis of silver supported on mesoporous titania nanoparticles}

The synthesis of Ag-MTN was carried out using a simple electrochemical method in accordance with procedure in the literature [11]. A closed-system electrolysis cell was fitted with a magnetic stirrer and a platinum plate cathode facing a silver plate anode. Then, MTN and TEAP were added to DMF. The electrolysis was conducted at a constant current of $240 \mathrm{~mA} \mathrm{~cm}$ and $273 \mathrm{~K}$ under air atmosphere to load $5 \mathrm{wt} \% \mathrm{Ag}$ on MTN. The sample was evaporated and dried at $383 \mathrm{~K}$ for 12 hours before calcination at $873 \mathrm{~K}$ for 3 hours to yield a grey powder catalyst donated Ag-MTN that is ready for characterisation and photocatalytic testing.

\section{Characterisation}

The crystalline structures of the catalysts were examined using a Bruker Advance D8 X-ray powder diffractometer (XRD) with $\mathrm{Cu} \mathrm{K} \alpha$ radiation of $\lambda=1.5418 \AA$ at $2 \theta$ angle ranging from $22^{\circ}$ to $66^{\circ}$. The phases were identified with the aid of the Joint Committee on Powder Diffraction Standards (JCPDS) files. The chemical functional groups present in the catalysts were identified by Fourier transform infrared (FTIR) spectroscopy (Perkin Elmer Spectrum GX FTIR spectrometer). IR absorbance data were obtained over a range of wavenumbers from 390 to $3700 \mathrm{~cm}^{-1}$. The morphological properties of the catalysts were examined by transmission electron microscopy (TEM, JEOL JEM2100F). Nitrogen adsorption-desorption isotherms were used to determine the textural properties at liquid nitrogen temperatures using a, SA 3100 Surface Analyzer (Beckman Coulter). The Brunauer-Emmett-Teller (BET) and nonlocal density functional theory (NLDFT) methods were used to calculate surface area and pore distribution, respectively. Prior to measurement, all samples were degassed at $300{ }^{\circ} \mathrm{C}$ and $0.1 \mathrm{~Pa}$. The X-ray photoelectron spectroscopy (XPS) was conducted in the range 0-800 eV using a Kratos Ultra spectrometer equipped with $\mathrm{Mg} \mathrm{K}_{\alpha}$ radiation source $(10 \mathrm{~mA}, 15 \mathrm{kV})$. A small Inox cylinder was used to press the powdered sample prior to analysis inside an analysis chamber pressure at about $1 \times 10^{-10} \mathrm{~Pa}$ to obtain the data. The binding energy of the $\mathrm{C}(1 \mathrm{~s})$ at peak $284.5 \pm 0.1 \mathrm{eV}$ was taken as the internal standard or reference as the solution to correct the energy shift. A JEOL JES-FA100 ESR spectrometer was used for the determination of surface defect $\mathrm{Ti}^{3+}$ and oxygen vacancy, where the sample was placed at about $2 \mathrm{~cm}$ height inside the glass vessel followed by the electron spin resonance (ESR) measurement to identify the g-value at room temperature. UV-Vis diffuse reflectance spectroscopy (UV-Vis DRS) was recorded in air at room temperature using a Perkin Elmer Lambda 900 UV/Vis/NIR spectrometer with an integrating sphere.

\section{Photodegradation of phenol derivatives}

The photoactivity of the catalysts was tested for the degradation of phenol derivatives. Four types of phenol derivatives were used: $\mathrm{Ph}, 2-\mathrm{CP}, 2,4-\mathrm{diCP}$, and 4-AcePh. The stock solutions of the phenol derivatives were prepared with the initial concentration of each derivative of $50 \mathrm{mgL}^{-1}$. The stock solutions of the phenol derivatives were mixed in the ratio of 1:1:1:1. The photocatalytic experiments were performed in a batch reactor fixed with a cooling system. A $39 \mathrm{~W}$ metal halide lamp $(400 \mathrm{~nm})$ was used as a visible light source.

For photoactivity evaluation, $0.375 \mathrm{gL}^{-1}$ of MTN was added to the phenol derivatives solution $(200 \mathrm{ml})$ and stirred for 1 hour in the dark to achieve adsorption-desorption equilibrium. The initial $\mathrm{pH}$ of the solution was $\mathrm{pH} 5$ and the reaction was carried out at $30^{\circ} \mathrm{C}$. Then, the reaction was carried out for another 6 hours under light irradiation under continuous stirring. The concentration of the sample was measured using UV-Vis spectrometer at the absorption bands of 270, 274, 285, and $248 \mathrm{~nm}$ for Ph, 2-CP, 2,4-diCP, and 4-AcePh, respectively. Similar procedure was used for $\mathrm{TiO}_{2}$ and $\mathrm{Ag}-\mathrm{MTN}$.

\section{Results and Discussion}

Figure 1 shows the XRD patterns of $\mathrm{TiO}_{2}, \mathrm{MTN}$, and $\mathrm{Ag}-\mathrm{MTN}$ in the range of $2 \theta=22-66^{\circ}$. A series of characteristic peaks was observed for $\mathrm{TiO}_{2}$ (Fig. 1a) with peaks at $25^{\circ}(101), 36.8^{\circ}(103), 37.5^{\circ}(004), 39^{\circ}(112)$, $47.5^{\circ}(200), 54^{\circ}(105), 56^{\circ}(211)$, and $63^{\circ}(204)$ that was consistent with the $\mathrm{TiO}_{2}$ anatase phase (JCPDS file no. 00004-0477). The XRD pattern of MTN was similar to $\mathrm{TiO}_{2}$. However, the peak intensity of MTN (Fig. 1b) seemed to be more intense compared with $\mathrm{TiO}_{2}$, which indicated that the crystallinity of MTN is better than $\mathrm{TiO}_{2}$. The XRD pattern of Ag-MTN catalyst (Fig. 1c) was similar to MTN (Fig.1b), which illustrated that the loading of Ag did not intrude the structure of MTN [12]. However, the peak intensity of MTN seemed to decrease with the addition of Ag, which indicated the degree of orderliness in MTN and mesoporous uniformity decreased but did not remarkably 
intrude the structure of catalyst [13]. Meanwhile, new diffraction peaks were observed at $32.35^{\circ}(200)$, 33.15 (111), and 57.2 $2^{\circ}(\overline{1} 13)$ after the Ag loading due to the plane of Ag for AgO moieties in Ag-MTN [14]. In addition, another two diffraction peaks at $27.5^{\circ}$ and $46.3^{\circ}$ showed the presence of traces of rutile and brookite. The crystallite size of the catalysts was calculated by the Debye-Scherrer equation based on the major peak $2 \theta=25^{\circ}$ as follows:

$$
\tau=\frac{k \lambda}{\beta \cos \theta}
$$

where $\tau$ is the particle size, $\lambda$ is the wavelength of $\mathrm{X}$-ray radiation $(\mathrm{Cu} \mathrm{K} \alpha=0.1542 \mathrm{~nm}), k$ is the shape factor $(k=$ 0.94), $\beta$ is the line width at half-maximum height, and $\theta$ is the angular position of the peak maximum. It was found that the size of $\mathrm{TiO}_{2}$ and MTN were 30.0 and $11.3 \mathrm{~nm}$, respectively. However, the addition of Ag onto MTN demonstrated the decrease in the crystallite size from 11.3 to $7.21 \mathrm{~nm}$, possibly due to the interaction of Ag and MTN. A similar observation was reported by Das et al., which revealed that the interaction of titania species with $\mathrm{ZrP}$ and $\mathrm{TiP}$ was the reason for the decrease in crystallite size of catalysts [15].

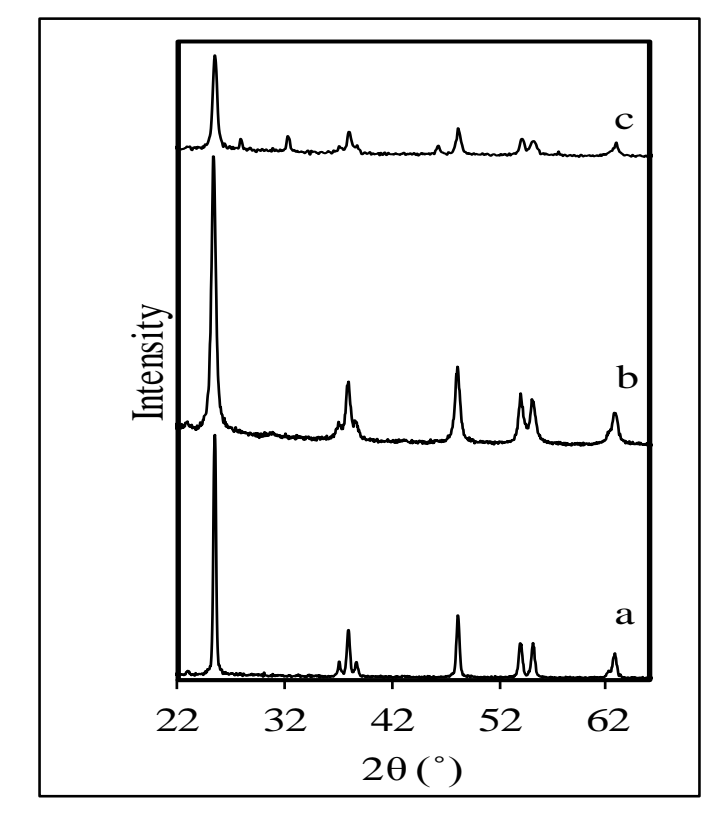

Figure 1. XRD diffractograms of (a) $\mathrm{TiO}_{2}$ (b) MTN and (c) Ag-MTN

The textural properties for all catalysts are summarised in Table 1. The results showed that MTN has higher surface area and pore volume compared to $\mathrm{TiO}_{2}$. This phenomenon indicates that the balance of heat distribution by microwave during the synthesis for hydrolysis and condensation may contribute to the framework cross-linking for better growth of smaller pores [16]. In contrast, the introduction of Ag onto MTN shows a decrease in surface area and pore volume probably due to the aggregation of Ag nanoparticles that blocks the pore surface of MTN. In addition, the introduction of $\mathrm{Ag}$ onto MTN also decreased the band gap from 3.11 to $3.05 \mathrm{eV}$. This result demonstrates that the anchoring of Ag to MTN surface helps to reduce the band gap of Ag-MTN catalyst. A similar trend was also observed by Khan et al. for the synthesis of $\mathrm{Ag} @ \mathrm{TiO}_{2}$ composite, in which the band gap of $\mathrm{TiO}_{2}$ decreased after the introduction of $\mathrm{Ag}$ from 3.33 to $2.86 \mathrm{eV}$ [17].

The morphology of the catalysts was then examined by TEM analyses and the images are shown in Figure 2 . The TEM images of $\mathrm{TiO}_{2}$ (Fig. 2a) and MTN (Fig. 2b) show translucent property with irregular shaped particles. Then, the TEM image of MTN (Fig. 2b) was compared with Ag-MTN (Fig. 2c) to study their morphology properties. The original morphology of MTN was interrupted by the introduction of Ag but by comparing with the translucent image of MTN, the distribution of Ag was clearly observed in Ag-MTN. This result confirmed that Ag nanoparticles dispersed well on the surface of MTN. 
Table 1. Textural properties of catalysts

\begin{tabular}{lccc}
\hline Catalyst & $\begin{array}{c}\text { Surface Area } \\
\left(\mathbf{m}^{\mathbf{2}} \mathbf{g}^{-\mathbf{1}}\right)\end{array}$ & $\begin{array}{c}\text { Pore Volume } \\
\left(\mathbf{c m}^{\mathbf{3}} \mathbf{g}^{-\mathbf{1}}\right)\end{array}$ & $\begin{array}{c}{ }^{\mathrm{a}} \text { Band Gap } \\
(\mathbf{e V})\end{array}$ \\
\hline $\mathrm{TiO}_{2}$ & 12.5 & 0.22 & 3.31 \\
$\mathrm{MTN}$ & 181 & 0.35 & 3.11 \\
$\mathrm{Ag}-\mathrm{MTN}$ & 100 & 0.31 & 3.05 \\
\hline
\end{tabular}

${ }^{a}$ Band gap calculated using $\mathrm{E}_{\mathrm{g}}=1240 / \lambda$
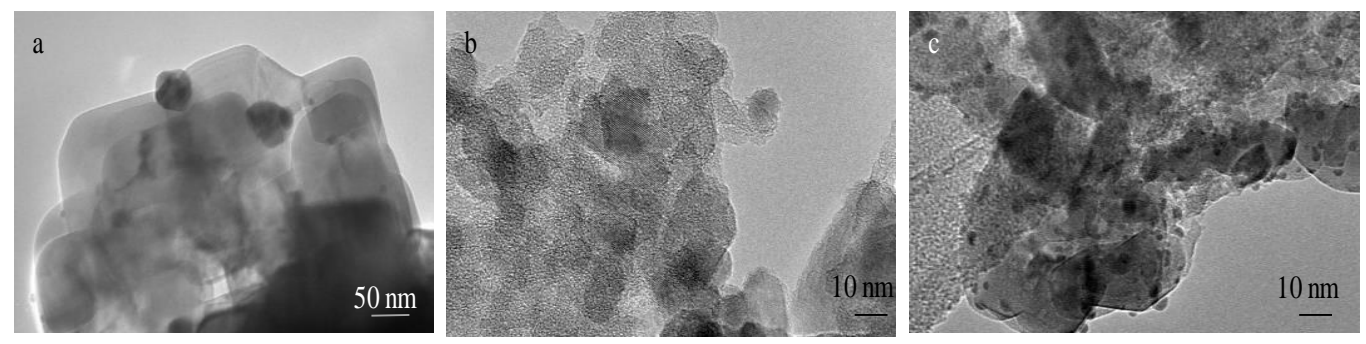

Figure 2. TEM images of (a) $\mathrm{TiO}_{2}$ (b) MTN and (c) Ag-MTN

Figure 3 shows the FTIR spectroscopy in the range of $2000-390 \mathrm{~cm}^{-1}$ for all the catalysts. All catalysts showed a band at $1625 \mathrm{~cm}^{-1}$ that corresponded to $\mathrm{OH}$ vibration of the surface-adsorbed water [18]. The bands observed at 1100 and $455 \mathrm{~cm}^{-1}$ for MTN (Fig. 3b) and Ag-MTN (Fig. 3c) were assigned to Ti-O-Ti asymmetric stretching and bending vibration modes, respectively [19]. However, $\mathrm{TiO}_{2}$ (Fig. 3a) illustrated that both of the bands were absent but a sharp band could be detected at $530 \mathrm{~cm}^{-1}$, which was attributed to the Ti-O-Ti bond of $\mathrm{TiO}_{2}$ anatase phase [20]. Besides, another new peak was also observed for $\mathrm{Ag}-\mathrm{MTN}$ at $650 \mathrm{~cm}^{-1}$ attributed to the $\mathrm{Ag}-\mathrm{O}$ bond, which illustrated that Ag nanoparticles were successfully introduced on MTN.

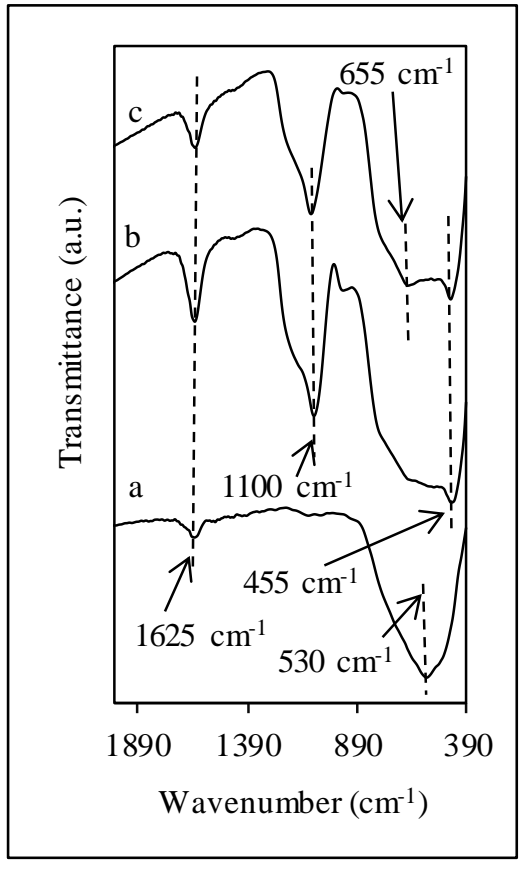

Figure 3. FTIR spectra in region $2000-390 \mathrm{~cm}^{-1}$ of (a) $\mathrm{TiO}_{2}$ (b) MTN and (c) Ag-MTN 
Chemical states of MTN and Ag-MTN were determined using XPS analysis as shown in Figure 4. Fig. 4A shows the wide scan for MTN and Ag-MTN. Titanium (Ti) and oxygen (O) were detected for both catalysts, while Ag could only be detected in Ag-MTN, as indexed in both catalysts. Fig. 4B(a) displays the region of Ti $2 \mathrm{p}_{3 / 2}$ with $\mathrm{Ti}^{3+}$ were observed at 457.7 and $458.9 \mathrm{eV}$ while the binding energies at 458.3 and $459.3 \mathrm{eV}$ were assigned to $\mathrm{Ti}^{4+}$ for MTN [21]. The region O 1s of MTN (Fig. 4C(a)) illustrated the existence of $\mathrm{Ti}^{3+}-\mathrm{O}$ at 530.8 and $532.5 \mathrm{eV}$, whereas the binding energies at 529.5 and $534.5 \mathrm{eV}$ were attributed to $\mathrm{Ti}^{4+}-\mathrm{O}$ and $\mathrm{OH}$ or $\mathrm{OH}^{-}$, respectively [22]. These results confirmed the presence of TSD in MTN. The XPS analysis of Ag-MTN showed that new regions were observed other than Ti 2p $\mathrm{p}_{3 / 2}$ (Fig. 4B(b)) and O 1s (Fig. 4C(b)), which were Ti 2p $\mathrm{p}_{1 / 2}$ (Fig. 4B(b)) and Ag 3d (Fig. 4D) prior to the introduction of $\mathrm{Ag}$ onto MTN. Fig. $4 \mathrm{~B}(\mathrm{~b})$ illustrated four binding energies in the region of Ti $2 \mathrm{p}_{3 / 2}$ at $458\left(\mathrm{Ti}^{3+}\right), 459\left(\mathrm{Ti}^{3+}\right), 458.4\left(\mathrm{Ti}^{4+}\right)$, and $459.5 \mathrm{eV}\left(\mathrm{Ti}^{4+}\right)$, with two binding energies at $462.8\left(\mathrm{Ti}^{4+}\right)$ and $464.7 \mathrm{eV}$ $\left(\mathrm{Ti}^{4+}\right)$ for the region of Ti $2 \mathrm{p}_{1 / 2}$ [17]. Meanwhile, $\mathrm{O} 1 \mathrm{~s}$ (Fig. $\left.4 \mathrm{C}(\mathrm{b})\right)$ region showed the binding energies at 530.4 and $532.7 \mathrm{eV}$ for peak $\mathrm{Ti}^{3+}-\mathrm{O}$, whereas the peaks at $\mathrm{Ti}^{4+}-\mathrm{O}$ and $\mathrm{OH}$ or $\mathrm{OH}^{-}$were observed at 529.5 and $534.5 \mathrm{eV}$, respectively. The presence of Ag nanoparticles was confirmed in Fig. 4D by the presence of binding energies at 368 and $374 \mathrm{eV}$, which were attributed to $\mathrm{Ag} 3 \mathrm{~d}_{5 / 2}$ and $\mathrm{Ag} 3 \mathrm{~d}_{3 / 2}$, respectively [23]. This result agrees with XRD (Fig. 1c) and FTIR (Fig. 3) analysis where $\mathrm{Ag}$ and $\mathrm{AgO}$ were detected.

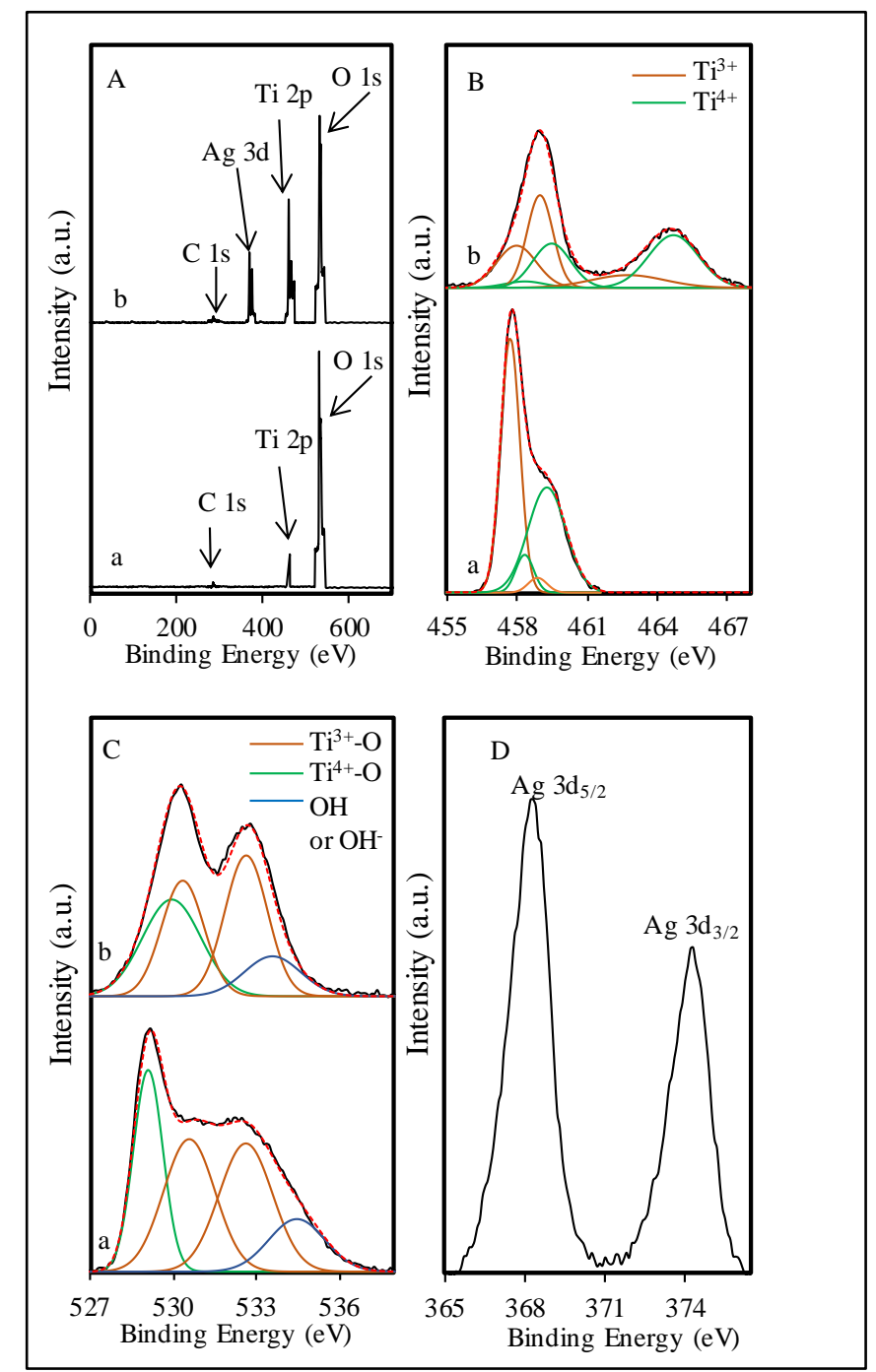

Figure 4. XPS spectra of (A) wide scan; (B) Ti 2p; (C) O 1s of (a) MTN and (b) Ag-MTN; and (D) Ag 3d of Ag-MTN 
In addition, ESR also further confirmed the presence of TSD and oxygen vacancies (OV) for the catalysts and the results are shown in Figure 5. Two signals corresponded to OV and TSD sites were observed at $\mathrm{g}=1.99$ and $\mathrm{g}=1.96$, respectively. The signal intensity of Ag-MTN (Fig. 5c) was the highest for both OV and TSD prior to the introduction of Ag onto MTN compared to MTN. However, the signal intensities of MTN (Fig. 5b) were higher compared to $\mathrm{TiO}_{2}$ (Fig. 5a). These results signify the presence of OV and TSD in all catalysts where these species are important elements in the photocatalytic process since this process mainly depends on OV and TSD [24].

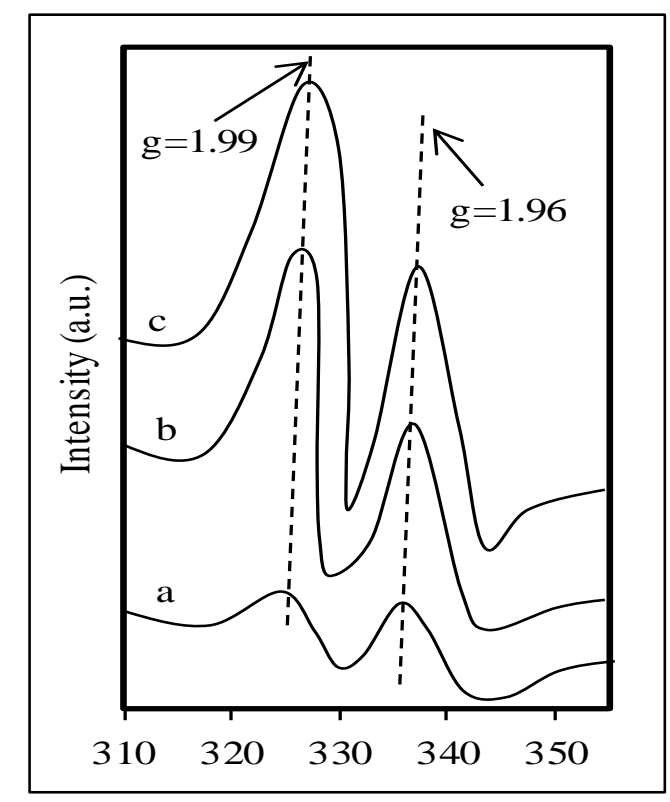

Figure 5. ESR of (a) $\mathrm{TiO}_{2}$ (b) MTN and (c) Ag-MTN

Figure 6 demonstrates the photocatalytic activities of the catalysts on the degradation of phenol derivatives. It could be observed that MTN showed higher performance on the degradation of phenol derivatives compared to $\mathrm{TiO}_{2}$. Photocatalytic degradation of phenol derivatives using MTN successfully degraded $80,92,70$, and $75 \%$ of $\mathrm{Ph}, 2$ $\mathrm{CP}, 2,4-\mathrm{diCP}$, and $4-\mathrm{Ace} \mathrm{Ph}$, respectively. In contrast, $\mathrm{TiO}_{2}$ only managed to degrade $15,20,25$, and $13 \%$ of $\mathrm{Ph}, 2$ $\mathrm{CP}, 2,4-\mathrm{diCP}$, and 4-AcePh, respectively. This phenomenon occurs may be due to numbers of OV and TSD for $\mathrm{TiO}_{2}$ that are lower than MTN, where the larger values of both species, the higher the photoactivity. These two species could act as the electron acceptor in order to decrease the electron-hole recombination, as well as the promoter in the oxidation of phenol derivatives since it could also adsorb $\mathrm{O}_{2}$ [25].

Meanwhile, Ag-MTN showed the highest degradation of phenol derivatives compared to $\mathrm{TiO}_{2}$ and MTN, in which Ag-MTN successfully degraded 85, 95, 80, and 79\% of Ph, 2-CP, 2,4-diCP, and 4-AcePh, respectively. This result is probably because Ag-MTN has the highest number of OV and TSD according to the ESR result (Fig. 5), which benefits the photocatalytic process by reducing the band gap energy of the catalyst. The decrease in the band gap of Ag-MTN could also improve photoactivity because it is expected that Ag nanoparticles will act as the electron acceptor after the visible light irradiation on MTN that leads to electron excitation from the valence band $\left(\mathrm{V}_{B}\right)$ to the existing OV and TSD before reaching the conduction band $\left(\mathrm{C}_{\mathrm{B}}\right)$. Consequently, this increases the concentration of photogenerated holes that play an important role at the catalyst surface. Besides, this result also illustrated the role of $\mathrm{Ag}$ as the electron trapper, which is attributed to the Schottky energy barrier formed between the interaction of $\mathrm{Ag}$ and MTN and plasmonic sensitizer to suppress the electron-hole recombination, where the synergistic effect between Ag and MTN plays an important role in the system. 


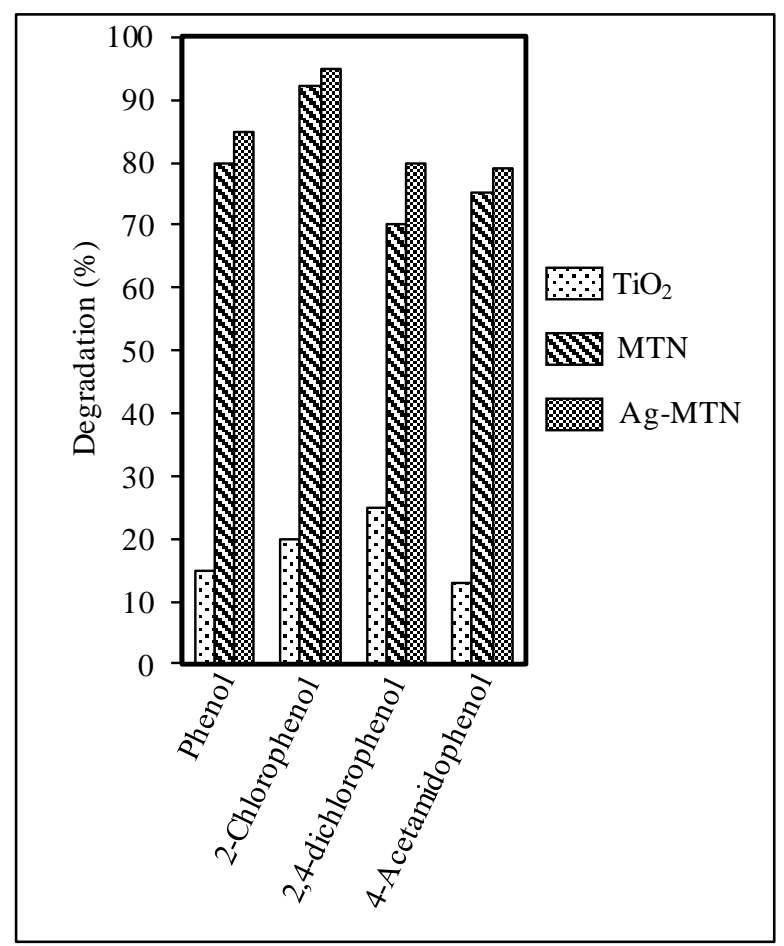

Figure 6. Photodegradation activity of $\mathrm{TiO}_{2}, \mathrm{MTN}$ and $\mathrm{Ag}-\mathrm{MTN}$ for degradation of simulated phenol derivatives $\left[\mathrm{C}_{\text {Phenol derivatives }}=50 \mathrm{mg} \mathrm{L}^{-1}, \mathrm{pH}=5, \mathrm{~W}=0.375 \mathrm{~g} \mathrm{~L}^{-1}, \mathrm{t}=6\right.$ hours, $\left.303 \mathrm{~K}\right]$

\section{Conclusion}

The introduction of Ag onto MTN demonstrated that it can be used as an effective photocatalyst for the degradation of phenol derivatives under visible light. The physicochemical properties of the catalysts were studied using XRD, TEM, FTIR, ESR, $\mathrm{N}_{2}$ adsorption desorption, UV-Vis DRS, and XPS. The analyses of UV-Vis DRS, ESR, and XPS verified that the introduction of Ag reduced the band gap of MTN and increased the number of OV and TSD, which seemed to play important roles for application under visible light. Ag-MTN gave the highest percentage degradation of phenol derivatives followed by MTN, while $\mathrm{TiO}_{2}$ showed the lowest degradation. The presence of Ag not only improved the properties of MTN to be applied under visible light but also acted as electron trapper and plasmonic sensitizer to enhance the photoactivity of catalyst. Thus, this modified catalyst has a great potential to be extended for degradation of various pollutants such as heavy metal, organic pollutants, and pharmaceutical wastes. Besides, by using the reported techniques (microwave-assisted method and electrochemical method), it is believed that further modification of other semiconductors can be also carried out to create various properties for various applications.

\section{Acknowledgement}

The authors are grateful for the financial support by the Ministry of Education Malaysia for Fundamental Research Grant (203.PKIMIA.6711607) and Universiti Sains Malaysia for Short Term Grant (304/PKIMIA/6315055). A special dedication to our late supervisor, Professor Sugeng Triwahyono for his endless advice. Thank you very much for everything.

\section{References}

1. Lindholm-Lehto, P. C., Knuutinen, J. S., Ahkola, H. S. and Herve, S. H. (2015). Refractory organic pollutants and toxicity in pulp and paper mill wastewaters. Environmental Science and Pollution Research, 22(9): 64736499 . 
2. Gryglik, D., Miller, J. S. and Ledakowicz, S. (2007). Singlet molecular oxygen application for 2-chlorophenol removal. Journal of Hazardous Materials, 146(3): 502-507.

3. Wang, S. L., Tzou, Y. M., Lu, Y. H. and Sheng, G. (2007). Removal of 3-chlorophenol from water using ricestraw-based carbon. Journal of Hazardous Materials, 147(1-2): 313-318.

4. Khan, M. Z., Mondal, P. K. and Sabir, S. (2011). Bioremediation of 2-cholorophenol containing wastewater by aerobic granules-kinetics and toxicity. Journal of Hazardous Materials, 190(1-3): 222-228.

5. Lee, J. S., You, K. H. and Park, C. B. (2012). Highly photoactive, low bandgap $\mathrm{TiO}_{2}$ nanoparticles wrapped by graphene. Advanced Materials, 24(8): 1084-1088.

6. Jaafar, N. F., Jalil, A. A. and Triwahyono, S. (2017). Visible-light photoactivity of plasmonic silver supported on mesoporous $\mathrm{TiO}_{2}$ nanoparticles (Ag-MTN) for enhanced degradation of 2-chlorophenol: Limitation of AgTi interaction. Applied Surface Science, 392: 1068-1077.

7. Xie, Y., Li, Y., and Zhao, X. (2007). Low-temperature preparation and visible-light-induced catalytic activity of anatase F-N-codoped $\mathrm{TiO}_{2}$. Journal of Molecular Catalysis A: Chemical, 277(1): 119-126.

8. Jaafar, N. F., Jalil, A. A., Triwahyono, S. and Shamsuddin, N. (2015). New insights into self-modification of mesoporous titania nanoparticles for enhanced photoactivity: effect of microwave power density on formation of oxygen vacancies and $\mathrm{Ti}^{3+}$ defects. RSC Advances, 5(110): 90991-91000.

9. Tian, J., Liu, R., Wang, G., Xu, Y., Wang, X. and Yu, H. (2014). Dependence of metallic Ag on the photocatalytic activity and photoinduced stability of $\mathrm{Ag} / \mathrm{AgCl}$ photocatalyst. Applied Surface Science, 319: 324-331.

10. Jalil, A. A., Triwahyono, S., Razali, N. A. M. Hairom, N. H. H., Idris, A., Muhid, M. N. M., Ismail, A., Yahaya, N. A. M., Ahmad, N. A. L. and Dzinun, H. (2010). Complete electrochemical dechlorination of chlorobenzenes in the presence of various arene mediators. Journal of Hazardous Materials, 174: 581-585.

11. Jalil, A. A., Kurono, N. and Tokuda, M. (2002). Facile synthesis of ethyl 2-arylpropenoates by cross-coupling reaction using electrogenerated highly reactive zinc. Tetrahedron, 58: 7477-7484.

12. Jaafar, N. F., Jalil, A. A., Triwahyono, S., Muhid, M. N. M., Sapawe, N., Satar, M. A. H. and Asaari, H. (2012). Photodecolorization of methyl orange over $\alpha-\mathrm{Fe}_{2} \mathrm{O}_{3}$-supported HY catalysts: The effects of catalyst preparation and dealumination. Chemical Engineering Journal, 191:112-122.

13. Kao, K. C. and Mou, C.Y. (2013). Pore-expanded mesoporous silica nanoparticles with alkanes/ethanol as pore expanding agent. Microporous and Mesoporous Materials, 169: 7-15.

14. Priyadharshini, R. I., Prasannaraj, G., Geetha, N. and Venkatachalam, P. (2014). Microwave-mediated extracellular synthesis of metallic silver and zinc oxide nanoparticles using macro-algae (Gracilaria edulis) extracts and its anticancer activity against human PC3 cell lines. Applied Biochemistry and Biotechnology, 174(8): 2777-2790.

15. Das, D. P., Baliarsingh, N. and Parida, K. M. (2007). Photocatalytic decolorisation of methylene blue (MB) over titania pillared zirconium phosphate $(\mathrm{ZrP})$ and titanium phosphate (TiP) under solar radiation. Journal of Molecular Catalysis A: Chemical, 261(2): 254-261.

16. Mori, Y. and Pinnavaia, T.J. (2001). Optimizing organic functionality in mesostructured silica: Direct assembly of mercaptopropyl groups in wormhole framework structures. Chemistry of Materials, 13(6): 2173-2178.

17. Khan, M. M., Ansari, S. A., Pradhan, D., Ansari, M. O., Lee, J. and Cho, M. H. (2014). Band gap engineered $\mathrm{TiO}_{2}$ nanoparticles for visible light induced photoelectrochemical and photocatalytic studies. Journal of Materials Chemistry A, 2(3): 637-644.

18. Mazinani, B., Masrom, A. K., Beitollahi, A. and Luque, R. (2014). Photocatalytic activity, surface area and phase modification of mesoporous $\mathrm{SiO}_{2}-\mathrm{TiO}_{2}$ prepared by a one-step hydrothermal procedure. Ceramics International, 40(8): 11525-11532.

19. Todan, L., Dascalescu, T., Preda, S., Andronescu, C., Munteanu, C., Culita, D.C., Rusu, A., State, R. and Zaharescu, M. (2014). Porous nanosized oxide powders in the $\mathrm{MgO}^{-\mathrm{TiO}_{2}}$ binary system obtained by sol-gel method. Ceramics International, 40(10): 15693-15701.

20. Jaafar N. F., Jalil A. A., Triwahyono S., Ripin A. and Ali M. W. (2016) Significant effect of pH on photocatalytic degradation of organic pollutants using semiconductor catalysts. Jurnal Teknologi (Sciences \& Engineering), 78(8-4): 7-12.

21. Yan, X. M., Kang, J., Gao, L., Xiong, L. and Mei, P. (2013). Solvothermal synthesis of carbon coated N-doped $\mathrm{TiO}_{2}$ nanostructures with enhanced visible light catalytic activity. Applied Surface Science, 265: 778-783. 
22. Huang, C. N., Bow, J. S., Zheng, Y., Chen, S.Y., Ho, N. J. and Shen, P. (2010). Nonstoichiometric titanium oxides via pulsed laser ablation in water. Nanoscale Research Letters, 5(6): 972-985.

23. Cheng, B. Le, Y. and Yu, J. (2010). Preparation and enhanced photocatalytic activity of $\mathrm{Ag} @ \mathrm{TiO}_{2}$ core-shell nanocomposite nanowires. Journal of Hazardous Materials, 177(1): 971-977.

24. Liu, H., Ma, H. T., Li, X. Z., Li, W. Z., Wu, M. and Bao, X. H. (2003). The enhancement of $\mathrm{TiO}_{2}$ photocatalytic activity by hydrogen thermal treatment. Chemosphere, 50(1): 39-46.

25. Neppolian, B., Wang, Q., Yamashita, H. and Choi, H. (2007). Synthesis and characterization of $\mathrm{ZrO}_{2}-\mathrm{TiO}_{2}$ binary oxide semiconductor nanoparticles: Application and interparticle electron transfer process. Applied Catalysis A: General, 333(2): 264-271. 